\title{
An Overview of the Potential Use of Ethno-Medicinal Plants Targeting the Renin-Angiotensin System in the Treatment of Hypertension
}

\author{
Pietro De Lange-Jacobs ${ }^{1}$, Asma Shaikh-Kader ${ }^{1}{ }^{1}$, Bianca Thomas ${ }^{1}$ \\ and Trevor T. Nyakudya $1,2, *$ (D) \\ 1 Department of Human Anatomy and Physiology, University of Johannesburg, Doornfontein Campus, \\ Corner Beit and Siemert Streets, Doornfontein, Johannesburg 2000, South Africa; \\ pdljacobs@uj.ac.za (P.D.L.-J.); akader@uj.ac.za (A.S.-K.); bthomas@uj.ac.za (B.T.) \\ 2 Department of Physiology, School of Medicine, Faculty of Health Sciences, University of Pretoria, \\ Pretoria 0002, South Africa \\ * Correspondence: trevor.nyakudya@up.ac.za; Tel.: +27-12-321-1679
}

Academic Editors: Laura De Martino and Derek J. McPhee

Received: 19 March 2020; Accepted: 22 April 2020; Published: 30 April 2020

\begin{abstract}
The development of risk factors associated with cardiovascular disorders present a major public health challenge in both developed countries and countries with emerging economies. Hypertension and associated complications including stroke and myocardial infarction have reached pandemic levels. Current management strategies of hypertension predominantly include the utilization of pharmaceutical drugs which are often associated with undesirable side effects. Moreover, the drugs are often too expensive for populations from resource-limited Southern African rural, and some urban, communities. As a result, most patients rely on ethno-medicinal plants for the treatment of a variety of diseases including cardiovascular and metabolic disorders. The effectiveness of these plants in managing several cardiovascular diseases has been attributed to the presence of bioactive phytochemical constituents. In this review, the treatment options that target the renin-angiotensin system (RAS) in the management of hypertension were summarized, with special emphasis on ethno-medicinal plants and their influence on the ACE1 RAS pathway. The dearth of knowledge regarding the effect of ethno-medicinal plants on the ACE2 pathway was also highlighted.
\end{abstract}

Keywords: hypertension; ethno-medicinal plants; renin-angiotensin system; ACE1; ACE2; Sub-Saharan Africa

\section{Hypertension and the Global Problem}

The worldwide incidence of cardiovascular and metabolic diseases is on the increase, as evidenced by the growing prevalence of hypertension, type 2 diabetes (T2DM), and obesity. In fact, the present epidemic of hypertension, obesity and metabolic disorders has been proposed as the primary cause for the lower life expectancy that has been predicted for the next generation [1]. A person is diagnosed as being hypertensive if they have a systolic blood pressure that is higher than $140 \mathrm{mmHg}$ or a diastolic pressure that is above $90 \mathrm{mmHg}$ [2]. Several factors such as the sex of an individual, age, obesity, urbanization and lifestyle choices (consumption of high-energy diet and physical inactivity) have consistently been associated with hypertension [3-5]. Hypertension remains a major problem in affluent Western societies, while its incidence is increasing in developing countries. The increasing prevalence of this non-communicable disease in developing countries has been shown to be associated with economic development, urbanization and lifestyle changes [4]. The prevalence of hypertension worldwide is predicted to increase from $26.4 \%$ in 2000 to $60 \%$ of the global population by 2025 [6]. Furthermore, a relatively recent epidemiology study conducted in 786 countries with 5.4 million 
participants suggested that the mortality rate attributed to hypertension was 7 million deaths per year worldwide [7].

Sub-Saharan Africa has a diversity of countries, ethnic groups and cultures with differences in socioeconomic status. According to [8], there may be significant variations in the prevalence of hypertension in urbanized, semi-urbanized, and non-industrialized, isolated rural areas. In lower income groups, the incidence of hypertension is believed to be increased by socio-economic stress and lack of exercise, while obesity, dietary excess, excessive alcohol consumption, and lack of exercise appear to increase the incidence of hypertension in higher income groups [8,9]. According to the African Regional Health Report [10], 80 million people suffered from hypertension in 2000 in Sub-Saharan Africa and the prediction is that by 2025, the figure will rise to 150 million. In South Africa, there are more than 6 million people with hypertension [11]. In fact, a recent study of 3820 participants older than 50 years found that approximately $78 \%$ suffered from hypertension, with a greater incidence in females $(56 \%)$ as compared to males (44\%) [4]. However, the risk of mortality from hypertension was greater in males than in females [10]. The rise in the incidence of hypertension in South Africa has been attributed to the rapid westernization characterized by the excessive consumption of high-energy diets and adoption of sedentary affluent lifestyles. The fact that one in four South Africans between the ages of 15 and 64 years suffer from hypertension reflects this and highlights the severity of hypertension in South Africa [5,12]. The prevalence of hypertension in the South African population may not necessarily be due to ethnic differences, but may be due to the differences in socio-demographic status [13]. However, Connor, et al. [14] reported that ethnicity affects the overall prevalence of hypertension in South Africa, with a higher incidence in the black population compared to other ethnic groups. In addition, black South Africans are twice as likely to suffer from strokes than white South Africans and appear to be more vulnerable to other cardiovascular complications such as heart failure [8,11]. It is possible that, in some ethnic groups, there is a decrease in awareness of the disease, leading to poor response and compliance with anti-hypertensive therapy. Poorly controlled hypertension contributes majorly to the general burden of diseases in the adult population and can lead to cerebrovascular diseases, myocardial infarctions, kidney disease or failure, as well as left ventricular hypertrophy, which could predispose to congestive heart failure. This can, however, be avoided by both prompt detection and cost-effective management of the condition [5]. Moreover, the epidemic of hypertension is confounded by the under-diagnosis of the disease [8]. It is therefore widely accepted that there is a dire need to improve the diagnosis and management of hypertension [8].

\section{Pathways Involved in the Renin-Angiotensin System}

The management of hypertension involves the use of pharmacological agents that target specific mechanisms, such as the renin angiotensin system (RAS), that are involved in the regulation of blood pressure. Examples of these include angiotensin-converting enzyme (ACE) inhibitors and beta-blockers. In the last twenty years, it was recognized that the classical RAS axis is much more complex than originally believed (Figure 1). This is due to the discovery of i) ACE2, which catalyses the formation of Angiotensin (Ang) (1-7) from Ang II [15,16] and ii) G-protein-coupled receptors for Ang (1-7) named Mas receptors [17] that have been found to mediate the vasodilatory effects of Ang (1-7). Although Ang (1-7) can also function via the angiotensin 2 (AT2) receptor to cause vasodilation, the affinity for these receptors appears to be very low [18]. Furthermore, Ang (1-7) antagonizes the effects of Ang II at the angiotensin 1 (AT1) receptors, while ACE inhibitors do not inhibit ACE2 [19]. ACE2 can also hydrolyze Ang I to Ang (1-9), which is consequently converted to Ang (1-7) by ACE.

The ability of ACE2 to metabolize Ang II is crucial in the modulation or control of blood pressure and hypertension [20]. Due to the vasodilatory effects of Ang (1-7), it has been shown to be involved in the prevention of hypertension and cardiac hypertrophy [21] and the genetic deletion of Mas receptors have been shown to impair cardiac function [22]. Ang (1-7) is found in the myocardium, but is lost in infarcted hearts [23]. Studies have indeed shown that low doses of Ang (1-7) increase cardiac output 
and antagonize the vasoconstriction induced by Ang II by causing vasodilatory responses and reduced vascular resistance [24].

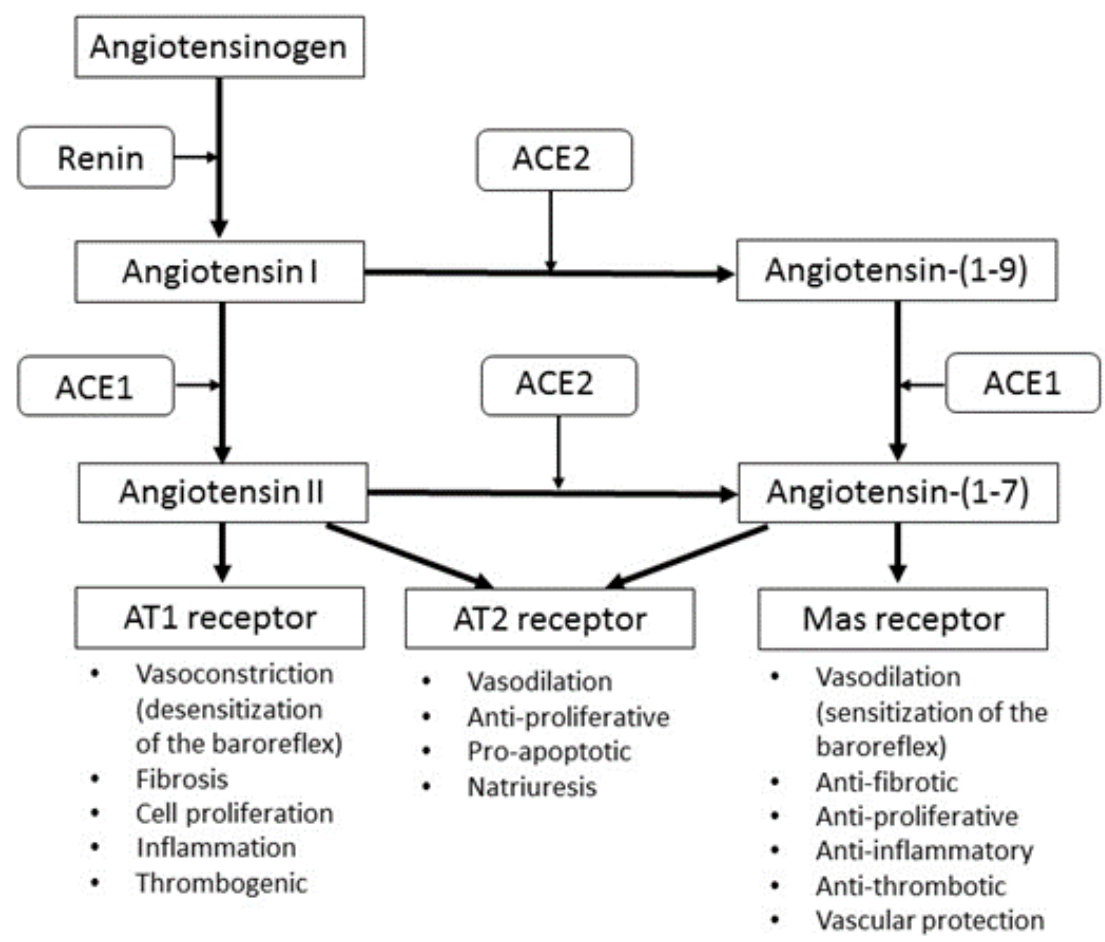

Figure 1. A current perspective of the ACE1 and ACE2 RAS pathways. ACE: angiotensin converting enzyme; AT: angiotensin.

Since ACE2 is the main enzyme involved in counterbalancing the Ang II vasoconstrictory and Ang (1-7) vasodilatory effect [19], it is suggested to play a role in cardiovascular diseases (CVDs) such as hypertension. It is possible that ACE2 over-expression can shift the balance towards Ang-(1-7) production, consequently decreasing the Ang II available to cause hypertensive effects [20]. The beneficial effects of ACE2 may therefore not necessarily be its production of Ang (1-7) from Ang II, but its capacity to lower Ang II and thereby prevent the detrimental cardiovascular effects of Ang II [20].

Existing treatment options for hypertension include pharmaceutical drugs that target the RAS pathway such as angiotensin receptor antagonists, ACE inhibitors and ACE2 activators. However, current research also focuses on the potential therapeutic effect of medicinal plants on these pathways.

\section{Disadvantages of Pharmaceutical Drugs in the Management of Hypertension}

Pharmaceutical management of hypertension is costly. In 1991, it contributed almost R5 billion in direct and indirect expenditure to the treatment of cardiovascular disease in South Africa [11]. Few people make the necessary lifestyle changes to improve their blood pressure, therefore most patients need antihypertensive medication for life. The consequence of this is two-fold: a decrease in the efficacy of antihypertensive medication due to prolonged usage and an increased incidence of adverse side effects such as coughing, loss of taste [25], erectile dysfunction [26], constipation and alopecia among others [27]. Although pharmaceutical treatment for hypertension exists, the inefficiency of the health care systems in Sub-Saharan Africa and the economic impact of expensive anti-hypertensive medication means that a large portion of the population find it challenging to adhere to or comply with the recommended treatment $[5,28]$. Furthermore, many hypertensive patients in developing countries of Sub-Saharan Africa do not have access to the expensive pharmaceutical anti-hypertensive medication due to several socio-economic challenges. It has also been shown that 
although ACE inhibitors have a good safety profile and are well tolerated, they are not safe to use during pregnancy [29].

As a result of these limitations associated with anti-hypertensive pharmaceutical products, and the fact that the incidence of hypertension is so rapidly increasing, there is an urgent need to find affordable, alternative or complementary treatments which are effective in reducing the development as well as the progression of hypertension and its symptoms. Of particular importance is prioritizing the research to develop an alternative or complementary approach that would increase the beneficial components of the RAS, especially the ACE2-Ang-(1-7)-Mas axis. Any safe, natural approach in the treatment of hypertension, which can be used with or without pharmaceutical drugs, is worth exploring.

\section{Use of Traditional Medicine in the Management of Hypertension}

Medicinal plants possess health-promoting characteristics and over $80 \%$ of the population in the world's developing countries rely on this medicinal source for their primary daily healthcare needs [30,31]. Evidence from literature shows that medicinal plants are used as a treatment option for a wide range of diseases, including hypertension and its complications [28]. The usage of medicinal plants for the treatment of hypertension has been documented in Asia, Europe, North America [32] and Africa [30].

The pharmacological and therapeutic properties of a number of medicinal plants that are currently used to manage hypertension by African communities are attributed to the presence of bio-active phytochemical constituents. These unique biologically active phytochemicals may improve health and alleviate the symptoms associated with hypertension either individually, additively or synergistically [30]. A review article by [28] on the use of medicinal plants in the treatment of hypertension in Sub-Saharan Africa and an ethno-pharmacological survey by Eddouks, et al. [33] have both highlighted the fact that scientifically sound information on the topic is scarce and further investigations in the bio-active compounds and action of the plant materials with anti-hypertensive properties need to be conducted. Although a few studies provide the very specific biological nomenclature for the plants used in the treatment of hypertension, (for example, in Nigeria, Azadirachta indica, Aloe vera and Cassia alata [28] and in Morocco, Allium sativum, Olea europaea and Pimpinella anusum [33]), the systematic identification of the medicinal plants used needs to be clarified.

Sixty five percent of South African adults in rural areas still depend on traditional medicines for their primary healthcare, however the extent of its use is not well documented $[5,28]$. Since medicinal plants still form an integral part of the culture in rural South Africa, patients diagnosed with hypertension in medical clinics or hospitals often approach traditional healers for treatment [34]. The most popular species used as an indigenous treatment for hypertension include Momordica balsamina, Hypoxis hemerocallidea and Aloe marlothii [35]. In an experimental animal study, eight plant species in Kwa-Zulu Natal were identified to have anti-hypertensive properties, with Tulbaghia violacea (wild garlic) holding the most promise [36]. Somova et al. [37] also experimentally found that Olea europaea subsp. africana showed potential in hypertension treatment. Therefore, broadening our knowledge on the use of ethno-medicinal plants in the treatment of hypertension is of paramount importance.

\section{Ethno-Medicinal Plants, Hypertension and the Effect on the ACE1 RAS Pathway}

Known medicinal plants that are currently used, or have the potential to lower blood pressure by influencing the ACE1 RAS pathway, are summarized in Table 1. Most of the medicinal plants used to treat hypertension possess ACE inhibitor activity. Plants considered to possess potential antihypertensive properties are required to inhibit the ACE enzyme (and the subsequent conversion of angiotensin I to angiotensin II) by more than $50 \%$ [12,38]. Studies have shown that methanol and aqueous extracts of some traditional plants such as Amaranthus hybridus, Amaranthus dubius, Justica flava, Asystasia gangetica, and Tulbaguia violacea, among others, show significant ACE1 inhibitory activity [39]. 
Table 1. Ethno-medicinal plants used in the treatment of hypertension by influencing the ACE1 renin-angiotensin (RAS) pathway.

\begin{tabular}{|c|c|c|c|c|c|}
\hline \multicolumn{2}{|c|}{ Species } & \multirow{2}{*}{$\begin{array}{c}\text { Mechanism } \\
\text { ACE1 inhibition }\end{array}$} & \multirow{2}{*}{$\begin{array}{c}\text { Bioactive Phytochemicals } \\
\text { Flavonoids }\end{array}$} & \multirow{2}{*}{$\begin{array}{c}\begin{array}{c}\text { Geographical } \\
\text { Distribution }\end{array} \\
\text { Southern Africa }\end{array}$} & \multirow{2}{*}{$\begin{array}{c}\text { Reference } \\
\begin{array}{c}\text { Duncan, Jäger and van } \\
\text { Staden [12] }\end{array}\end{array}$} \\
\hline${ }^{*}$ Adenopodia spicata & Spiny splinter bean & & & & \\
\hline * Agapanthus africanus & African lily & ACE1 inhibition & $\begin{array}{c}\text { Flavonoids } \\
\text { Sitosterol, yuccagenin, agapanthagenin, } \\
\text { spirostan sapogenins. }\end{array}$ & South Africa & $\begin{array}{l}\text { Duncan, Jäger and van } \\
\text { Staden [12] }\end{array}$ \\
\hline${ }^{*}$ Agave Americana & $\begin{array}{l}\text { Century plant, } \\
\text { maguey, or American } \\
\text { aloe }\end{array}$ & ACE1 inhibition & $\begin{array}{c}\text { Flavonoids } \\
\text { mono-2-ethylhexyl phthalate, } \\
\text { 1,2-benzenedicarboxylic acid, n-docosane, } \\
\text { and eicosane }\end{array}$ & Mexico, USA & $\begin{array}{l}\text { Duncan, Jäger and van } \\
\text { Staden [12] }\end{array}$ \\
\hline Allium sp. & Wild Garlic & $\begin{array}{l}\text { Decrease circulating } \\
\text { angiotensin II }\end{array}$ & Allicin & $\begin{array}{l}\text { Indigenous: Central } \\
\text { Asia } \\
\text { Currently found } \\
\text { worldwide }\end{array}$ & Preuss, et al. [43] \\
\hline${ }^{*}$ Amaranthus dubius & $\begin{array}{l}\text { Red spinach, Chinese } \\
\text { spinach, wild spinach }\end{array}$ & ACE1 inhibition & $\begin{array}{c}\text { Flavonoids } \\
\text { Niacin, thiamine, riboflavin, ascorbic acid, } \\
\text { hydrocyanic acid, oxalic acid }\end{array}$ & $\begin{array}{l}\text { Indigenous: China } \\
\text { Currently found } \\
\text { worldwide }\end{array}$ & $\begin{array}{c}\text { Ramesar, Baijnath, } \\
\text { Govender and Mackraj } \\
{[38]}\end{array}$ \\
\hline * Amaranthus hybridus & $\begin{array}{l}\text { Smooth amaranth, } \\
\text { smooth pigweed }\end{array}$ & ACE1 inhibition & $\begin{array}{l}\text { Flavonoids, steroids, terpenoids, cardiac } \\
\text { glycosides }\end{array}$ & North America & $\begin{array}{c}\text { Ramesar, Baijnath, } \\
\text { Govender and Mackraj } \\
{[38]}\end{array}$ \\
\hline Aronia melanocarpa & Chokeberry & Weak ACE1 inhibition & Polyphenols & North America & Sikora, et al. [44] \\
\hline Aspalathus linearis & Rooibos & ACE1 inhibition & Flavonoids, polyphenols & $\begin{array}{l}\text { Western Cape, South } \\
\text { Africa }\end{array}$ & Persson [42] \\
\hline${ }^{*}$ Asystasia gangetica & Creeping foxglove & ACE1 inhibition & $\begin{array}{c}\text { Flavonoids } \\
\text { Alkaloids, terpenes, salidroside, apigenin, } \\
\text { ajugol, megastigmaneglucoside, benzyl } \\
\beta \text {-D-glucopyranoside }\end{array}$ & Tropics & $\begin{array}{c}\text { Ramesar, Baijnath, } \\
\text { Govender and Mackraj } \\
\text { [38] }\end{array}$ \\
\hline Berberis integerrima & Barberry & ACE1 inhibition & $\begin{array}{l}\text { Flavonoids, flavinols, flavonols, } \\
\text { anthocynins, isoflavones, flavones, and } \\
\text { other phenolic compounds. }\end{array}$ & Iran & $\begin{array}{l}\text { Kearney, Whelton, } \\
\text { Reynolds, Muntner, } \\
\text { Whelton and He [6] }\end{array}$ \\
\hline Caragana microphylla & Littleleaf Peashrub & ACE1 inhibition & $\begin{array}{l}\text { Flavonoids, flavinols, flavonols, } \\
\text { anthocynins, isoflavones, flavones, and } \\
\text { other phenolic compounds. }\end{array}$ & Mongolia, China & $\begin{array}{l}\text { Kearney, Whelton, } \\
\text { Reynolds, Muntner, } \\
\text { Whelton and He [6] }\end{array}$ \\
\hline Cecropia glaziovii & Pumpwood (guarumo) & ACE1 inhibition & Flavonoids and proanthocyanidins & $\begin{array}{l}\text { S. America-southern } \\
\text { and eastern Brazil }\end{array}$ & Lacaille-Dubois, et al. [45] \\
\hline
\end{tabular}


Table 1. Cont.

\begin{tabular}{|c|c|c|c|c|c|}
\hline \multicolumn{2}{|c|}{ Species } & \multirow{2}{*}{$\begin{array}{c}\text { Mechanism } \\
\begin{array}{c}\text { Weak ACE1 inhibitory } \\
\text { effect }\end{array}\end{array}$} & \multirow{2}{*}{$\begin{array}{c}\text { Bioactive Phytochemicals } \\
\text { Bioflavonoids and proanthocyanidins }\end{array}$} & \multirow{2}{*}{$\begin{array}{c}\begin{array}{c}\text { Geographical } \\
\text { Distribution }\end{array} \\
\begin{array}{c}\text { North America and } \\
\text { Europe }\end{array}\end{array}$} & \multirow{2}{*}{$\begin{array}{c}\text { Reference } \\
\text { Brixius, et al. [46] } \\
\text { Rawat, et al. [47] }\end{array}$} \\
\hline Crataegus spp & Hawthorn & & & & \\
\hline${ }^{*}$ Dietes iridioides & African iris, Cape iris & ACE1 inhibition & Flavonoids & Sub-Saharan Africa & $\begin{array}{l}\text { Duncan, Jäger and van } \\
\text { Staden [12] }\end{array}$ \\
\hline Galinsoga parviflora & Potato weed & ACE1 inhibition & Not known & $\begin{array}{l}\text { Central America. } \\
\text { Currently found } \\
\text { worldwide }\end{array}$ & $\begin{array}{l}\text { Ramesar, Baijnath, } \\
\text { Govender and Mackraj [38] }\end{array}$ \\
\hline Guazuma ulmifolia & West Indian elm & $\begin{array}{l}\text { Inhibits binding } \\
\text { of Ang II to } \\
\text { angiotensin II type } 1 \\
\text { receptor }\end{array}$ & Proanthocyanidins & Central America & Caballero-George, et al. [48] \\
\hline Hibiscus sabderiffa & Hibiscus & ACE1 inhibition & $\begin{array}{l}\text { Anthocyanins } \\
\text { (delphinidin-3-sambubiocyde and } \\
\text { cynadine-3-sambubiocyde) }\end{array}$ & $\begin{array}{l}\text { Africa, South East Asia, } \\
\text { and Central America }\end{array}$ & Ojeda, et al. [49] \\
\hline Ipomoea reniformis & Morning glory & ACE1 inhibition & Polyphenols & $\begin{array}{l}\text { Subcontinent of Asia, } \\
\text { China, Indonesia, } \\
\text { Australia and Africa }\end{array}$ & Jabeen and Aslam [50] \\
\hline * Justicia flava & $\begin{array}{l}\text { Water-willow and } \\
\text { shrimp plant }\end{array}$ & ACE1 inhibition & $\begin{array}{c}\text { Flavonoids } \\
\text { Sterols, salicyclic acid, lignins, docosanoic } \\
\text { acid }\end{array}$ & $\begin{array}{l}\text { tropical to warm } \\
\text { temperate regions } \\
\text { worldwide }\end{array}$ & $\begin{array}{l}\text { Ramesar, Baijnath, } \\
\text { Govender and Mackraj [38] }\end{array}$ \\
\hline * Mesembryanthemum sp. & $\begin{array}{l}\text { Fig marigold or Icicle } \\
\text { plant }\end{array}$ & ACE1 inhibition & $\begin{array}{c}\text { Flavonoids } \\
\text { Betanidin, isobetanin, sterols, sapogenines, } \\
\text { triterpenes, tannins and alkaloids }\end{array}$ & Southern Africa & $\begin{array}{l}\text { Duncan, Jäger and van } \\
\text { Staden [12] }\end{array}$ \\
\hline Musanga cecropioides & Corkwood & ACE1 inhibition & Flavonoids and proanthocyanidins & Tropical Africa & $\begin{array}{c}\text { Lacaille-Dubois, Franck and } \\
\text { Wagner [45] }\end{array}$ \\
\hline Nigella sativa & Black cumin & ACE1 inhibition & Thymoquinone and polyphenols & $\begin{array}{l}\text { Middle } \\
\text { East, India and } \\
\text { Northern Africa }\end{array}$ & Jaarin, et al. [51] \\
\hline Nymphaea alba & White waterlily & ACE1 inhibition & $\begin{array}{l}\text { Flavonoids, flavinols, flavonols, } \\
\text { anthocynins, isoflavones, flavones, and } \\
\text { other phenolic compounds. }\end{array}$ & $\begin{array}{l}\text { Europe, Middle East } \\
\text { and North Africa }\end{array}$ & $\begin{array}{l}\text { Kearney, Whelton, } \\
\text { Reynolds, Muntner, } \\
\text { Whelton and He [6] }\end{array}$ \\
\hline Ocimum gratissimum & African basil & ACE1 inhibition & $\begin{array}{l}\text { Phenolic } \\
\text { compound, rutin }\end{array}$ & $\begin{array}{c}\text { Africa, Madagascar, } \\
\text { Southern Asia } \\
\text { Naturalized in the West } \\
\text { Indies and surrounding } \\
\text { countries }\end{array}$ & Shaw, et al. [52] \\
\hline $\begin{array}{l}\text { Olea europaea subsp. } \\
\text { Africana }\end{array}$ & Wild olive & ACE1 inhibition & $\begin{array}{l}\text { Oleuropein, esculin, ursolic acid, scopolin } \\
\text { and oleanolic acid }\end{array}$ & Africa & Msomi and Simelane [53] \\
\hline
\end{tabular}


Table 1. Cont.

\begin{tabular}{|c|c|c|c|c|c|}
\hline \multicolumn{2}{|c|}{ Species } & \multirow{2}{*}{$\begin{array}{c}\text { Mechanism } \\
\text { ACE1 inhibition }\end{array}$} & \multirow{2}{*}{$\begin{array}{l}\text { Bioactive Phytochemicals } \\
\text { Flavonoids, flavinols, flavonols, } \\
\text { thocynins, isoflavones, flavones, and } \\
\text { other phenolic compounds. }\end{array}$} & \multirow{2}{*}{$\begin{array}{c}\begin{array}{c}\text { Geographical } \\
\text { Distribution }\end{array} \\
\text { Europe, northern Africa, } \\
\text { the Canary Islands, the } \\
\text { Caucasus, and } \\
\text { southwest and central } \\
\text { Asia. }\end{array}$} & \multirow{2}{*}{$\begin{array}{l}\text { Reference } \\
\\
\text { Kearney, Whelton, } \\
\text { Reynolds, Muntner, } \\
\text { Whelton and He [6] }\end{array}$} \\
\hline Onopordum acanthium & Cotton thistle & & & & \\
\hline Oxygonum sinuatum & Double thorn & ACE1 inhibition & Not known & Sub-Saharan Africa & $\begin{array}{l}\text { Ramesar, Baijnath, } \\
\text { Govender and Mackraj [38] }\end{array}$ \\
\hline Peperomia pellucida & Shiny bush & ACE1 inhibition & $\begin{array}{l}\text { Terpenoids, Glycosides, } \\
\text { Antraquinones, Tannins }\end{array}$ & Indonesia & Saputri, et al. [54] \\
\hline Physalis viscosa & Sticky gooseberry & ACE1 inhibition & Not known & $\begin{array}{l}\text { South America, } \\
\text { Naturalised world-wide }\end{array}$ & $\begin{array}{l}\text { Ramesar, Baijnath, } \\
\text { Govender and Mackraj [38] }\end{array}$ \\
\hline * Protorhus longifolia & Red beech & ACE1 inhibition & $\begin{array}{l}\text { Flavonoids } \\
\text { Triterpenes }\end{array}$ & South Africa, Swaziland & $\begin{array}{l}\text { Duncan, Jäger and van } \\
\text { Staden [12] }\end{array}$ \\
\hline Quercus infectoria & Aleppo oak & ACE1 inhibition & $\begin{array}{c}\text { Flavonoids, flavinols, flavonols, } \\
\text { anthocynins, isoflavones, flavones, and } \\
\text { other phenolic compounds. }\end{array}$ & Greece, Asia minor & $\begin{array}{l}\text { Kearney, Whelton, } \\
\text { Reynolds, Muntner, } \\
\text { Whelton and He [6] }\end{array}$ \\
\hline Rosa rugose & Beach rose & ACE1 inhibition & Not known & $\begin{array}{l}\text { East Asia } \\
\text { Naturalised in Europe } \\
\text { and North America }\end{array}$ & Xie and Zhang [55] \\
\hline Rubus sp. & Berries & ACE1 inhibition & $\begin{array}{l}\text { Flavonoids, flavinols, flavonols, } \\
\text { anthocynins, isoflavones, flavones, and } \\
\text { other phenolic compounds. }\end{array}$ & North America, Europe & $\begin{array}{l}\text { Kearney, Whelton, } \\
\text { Reynolds, Muntner, } \\
\text { Whelton and He [6] }\end{array}$ \\
\hline Tulbaghia violacea & Garlic & $\begin{array}{l}\text { Reduced BP-ACE1 } \\
\text { and } \beta 1 \text { inhibition } \\
\text { (may not act via AT1 } \\
\text { receptors or } \alpha 1 \\
\text { receptors) }\end{array}$ & Bioflavonoids, steroidal saponins & South Africa, Zimbabwe & $\begin{array}{c}\text { Duncan, Jäger and van } \\
\text { Staden [12] } \\
\text { Mackraj, Ramesar and } \\
\text { Singh [36] } \\
\text { Raji, Mugabo and Obikeze } \\
\text { [40] } \\
\text { Raji, Obikeze and Mugabo } \\
\text { [41] } \\
\text { Ramesar, Baijnath, } \\
\text { Govender and Mackraj [38] }\end{array}$ \\
\hline Viola mandshurica & Manchurian violet & ACE1 inhibition & Not known & $\begin{array}{c}\text { East Asian } \\
\text { region, China, Taiwan, } \\
\text { Mongolia, Japan, Russia } \\
\text { and the } \\
\text { Far East }\end{array}$ & Huh [56] \\
\hline Zingiber ottensii & Red beehive ginger & ACE 1 inhibition & Bioactive protein peptides & $\begin{array}{l}\text { Tropics of Africa, Asia } \\
\text { and the Americas }\end{array}$ & Yodjun, et al. [57] \\
\hline
\end{tabular}

* Plants aqueous or ethanolic extracts inhibited the ACE enzyme by greater than $50 \%$ and tested negative for tannins using the gelatin salt block test. 
Most research has been done on plants such as wild garlic, hibiscus, black cumin and chokeberry that are indigenous to the Old-World countries and, due to their known medicinal and culinary properties, have spread worldwide for centuries. In the last decade, interest in the use of medicinal plants indigenous to other continents has been on the rise and recent research indicates that several indigenous African plant species have the potential to lower hypertension by influencing the conventional RAS pathway. The plant species indigenous to Southern Africa that show the most promising effect on ACE1 inhibition include Tulbaghia violacea [12,36,40,41], Aspalathus linearis [42] and Mesembryanthemum sp. [12]. Flavonoids (sub-groups: flavones, flavanones, isoflavones, flavan-3-ols, anthocyanins and flavonols) are the largest group of polyphenolic compounds found in plants and were found to be the most common active compound in most of the plant species listed in Table 1. Other polyphenols such as tannins, allicin and terpenoids also have ACE1 inhibitory effects.

\section{The ACE2 Pathway and the Effect on Hypertension}

In vitro [58] and in vivo [59] studies have shown that stimulation of ACE2 expression in hypertensive animals prevents cardiac hypertrophy, suggesting that ACE2 has a potential cardioprotective function. ACE2 also lowers blood pressure by increasing the sensitivity of the baroreflex [20]. Ang II, on the other hand, has opposite effects to ACE2 and acts through AT1R to desensitize the baroreflex, increase arginine vasopressin (AVP) secretion and activate the sympathetic nervous system, causing an increase in blood pressure [60]. ACE2 is mainly expressed in the testis, heart and kidneys [15], as well as in the liver, intestines and lungs [61,62]. ACE2 expression has been observed in the brain [63] where it is presumed to function as a central regulator of heart function [64]. Over-expression of ACE2 in the brain has been shown to alleviate hypertension, while inhibition of ACE2 activity with MLN-4760, an ACE2 receptor blocker, has been shown to attenuate the baroreflex and increase blood pressure [64].

Since its discovery in $2000[15,16]$ ACE2 has been targeted as a potential therapeutic agent for decreasing blood pressure and treating hypertensive patients. Evidence to support the potential beneficial role of ACE2 in CVDs comes from the fact that: (i) ACE2 activity and expression increase in the initial stages of heart failure, but decrease with the progression of the disease [65], (ii) over-expression of ACE2 in hypertensive rats infused with Ang II prevents cardiac hypertrophy [66], (iii) lower levels of ACE2 are shown to be associated with cardiac and renal pathologies in animal models [67] and (iv) over-expressed ACE2 gene transfer after neonatal development protects against elevated blood pressure and cardiac pathology in spontaneously hypertensive (SHR) models [59].

\section{Therapeutic Substances Targeting the ACE2 Pathway}

\subsection{Pharmaceutical Drugs Prescribed for Hypertension Influencing the ACE2 Pathway}

In the last decade, pharmacological research has identified active ingredients and developed drugs that influence the ACE2 pathway. These drugs and their mechanisms of action are summarized in Table 2. 
Table 2. Pharmaceutical drugs targeting the ACE2 pathway.

\begin{tabular}{|c|c|c|c|}
\hline Category of Action & Mechanism of Action & Examples of Drugs/Active Ingredient & References \\
\hline \multirow{22}{*}{ 1. ACE2 activators } & \multirow{2}{*}{ Decrease expression of ACE } & Felodipine combined with puerarin * & Bai, et al. [68] \\
\hline & & Ibuprofen \# & Qiao, et al. [69] \\
\hline & \multirow{2}{*}{ Decrease expression of AT1R } & Felodipine combined with puerarin * & Bai, Huang, Chen, Wang and Ding [68] \\
\hline & & Ibuprofen \# & Qiao, Wang, Chen, Zhang, Liu, Lu, Guo, Yan, Sun and Hu [69] \\
\hline & \multirow{3}{*}{$\begin{array}{l}\text { Decrease expression of serum } \\
\text { Ang II }\end{array}$} & Felodipine combined with puerarin * & Bai, Huang, Chen, Wang and Ding [68] \\
\hline & & Ibuprofen \# & Qiao, Wang, Chen, Zhang, Liu, Lu, Guo, Yan, Sun and Hu [69] \\
\hline & & Candesartan CILEXETIL \# & Arumugam, et al. [70] \\
\hline & \multirow{5}{*}{ Increase expression of ACE 2} & Felodipine combined with puerarin * & Bai, Huang, Chen, Wang and Ding [68] \\
\hline & & Ibuprofen \# & Qiao, Wang, Chen, Zhang, Liu, Lu, Guo, Yan, Sun and Hu [69] \\
\hline & & Propofol * & Cao, et al. [71] \\
\hline & & Telmisartan \# & Sukumaran, et al. [72] \\
\hline & & Xanthenone and resorcinolnaphthalein * & Hernández Prada, et al. [73] \\
\hline & \multirow{5}{*}{$\begin{array}{l}\text { Increase expression of } \\
\text { Ang-(1-7) }\end{array}$} & Candesartan CILFXFTU * & Arumugam, Thandavarayan, Palaniyandi, Giridharan, \\
\hline & & & Arozal, Sari, Soetikno, Harima, Suzuki and Kodama [70] \\
\hline & & Felodipine combined with puerarin * & Bai, Huang, Chen, Wang and Ding [68] \\
\hline & & Ibuprofen \# & Qiao, Wang, Chen, Zhang, Liu, Lu, Guo, Yan, Sun and Hu [69] \\
\hline & & $\begin{array}{l}\text { TBTIF (4-tert-butyl-2,6-bis } \\
\text { (thiomorpholin-4-ylmethyl)phenol) \# }\end{array}$ & Flores-Monroy, et al. [74] \\
\hline & \multirow{5}{*}{$\begin{array}{l}\text { Increase expression of Mas } \\
\text { receptor }\end{array}$} & & Arumugam, Thandavarayan, Palaniyandi, Giridharan, \\
\hline & & Candesartan CILEXETIL \# & Arozal, Sari, Soetikno, Harima, Suzuki and Kodama [70] \\
\hline & & Felodipine combined with puerarin * & Bai, Huang, Chen, Wang and Ding [68] \\
\hline & & Ibuprofen \# & Qiao, Wang, Chen, Zhang, Liu, Lu, Guo, Yan, Sun and Hu [69] \\
\hline & & Telmisartan \# & $\begin{array}{l}\text { Sukumaran, Veeraveedu, Gurusamy, Lakshmanan, } \\
\text { Yamaguchi, Ma, Suzuki, Kodama and Watanabe [72] }\end{array}$ \\
\hline $\begin{array}{l}\text { 2. Ang-(1-7) Mas receptor } \\
\text { agonist }\end{array}$ & $\begin{array}{l}\text { Increase activation of Mas } \\
\text { receptor }\end{array}$ & AVE 0991 \# & Santos, Ferreira and e Silva [22] \\
\hline
\end{tabular}




\subsection{Ethno-Medicinal Plants Influencing the ACE2 Pathway}

In vitro and in vivo studies have been conducted to test the ACE inhibitory capacity of medicinal plants (Table 1), but there is a dearth of information on the potential effect of these plants on the ACE2-angiotensin-(1-7)-Mas receptor axis. Table 3 summarizes the ethno-medicinal plants that have been shown to work through this axis and, moreover, highlights the lack of knowledge and research on the effect of medicinal plants on this axis. Currently there is no evidence of research in this field in Sub-Saharan Africa.

Table 3. Ethno-medicinal plants influencing the ACE2 pathway.

\begin{tabular}{|c|c|c|c|c|}
\hline Species & Mechanism & $\begin{array}{c}\text { Bioactive } \\
\text { Phytochemicals }\end{array}$ & $\begin{array}{l}\text { Geographical } \\
\text { Distribution }\end{array}$ & Reference \\
\hline $\begin{array}{c}\text { Qishenyiqi } \\
\text { (Radix Astragali } \\
\text { Mongolici, salvia } \\
\text { miltiorrhiza bunge, Flos } \\
\text { Lonicerae, scrophularia, } \\
\text { Radix Aconiti Lateralis } \\
\text { Preparata, Radix } \\
\text { Glycyrrhizae) }\end{array}$ & $\begin{array}{l}\text { Blocks effect of } \\
\text { Ang II by acting on } \\
\text { AT1R and AT2 } \\
\text { RIncreases ACE2 }\end{array}$ & Not known & East Asia & $\begin{array}{c}\text { Wang, et al. } \\
\text { [75] }\end{array}$ \\
\hline $\begin{array}{l}\text { Rosmarinus officinalis } \\
\text { Linn. }\end{array}$ & $\begin{array}{c}\text { Decreases ACE } \\
\text { expression and } \\
\text { increases ACE2 } \\
\text { expression, } \\
\text { decreases } \\
\text { expression of AT1R }\end{array}$ & Rosmarinic acid & $\begin{array}{c}\text { Mediterranean } \\
\text { region, but } \\
\text { widely cultivated }\end{array}$ & Liu, et al. [76] \\
\hline Scutellaria baicalensis & $\begin{array}{l}\text { Enhances ACE2 } \\
\text { protein expression }\end{array}$ & $\begin{array}{l}\text { Flavonoids } \\
\text { (Baicalin) }\end{array}$ & North America & $\begin{array}{c}\text { Zhang, et al. } \\
\text { [77] }\end{array}$ \\
\hline
\end{tabular}

\section{Challenges and Future Prospects of Using Anti-Hypertensive Medicinal Plants}

In light of the socio-economic challenges that societies in rural Southern Africa face, the use of ethno-medicinal plants is a cheaper and more accessible alternative to pharmaceutical anti-hypertensive therapeutic drugs [78]. There is also a general perception that medicinal plants are inherently safe and natural by those that utilize them for their primary healthcare and as anti-hypertensive remedies [79]. The use of medicinal plants is also associated with cultural preference and preservation of indigenous knowledge systems that have been passed down the generations [80,81].

Despite the numerous advantages associated with the use of anti-hypertensive medicinal plant products, there are several challenges that have been identified as well. Some of these challenges include the lack of standardization of plant preparations (for example, raw, boiled, and steeping), considering that different plant species have different potencies and will affect the dosage needed. Furthermore, the different parts of the plant used and the season during which the plant material is harvested must also be considered due to the differences in the phytochemical composition in different parts of these plants. In most cases, the use of plant products for the treatment of hypertension and other diseases, particularly in rural areas, is based on anecdotal evidence. Research targeted at the identification of active phytochemicals in medicinal plants seem to be the other viable option for supporting the efficacy claims for all anti-hypertensive medicinal plants. However, studies have shown that the type of extract used (aqueous or ethanolic) when determining the phytochemical composition of these plants yields different activity results [12]. Therefore, the methodology used in this research field needs to be standardized.

To our knowledge, with a few exceptions such as rooibos, most of the plant species currently used for medicinal purposes are not cultivated as crops but occur in the wild. However, it is possible for these plants to be contaminated with xenobiotic compounds found in pesticides through ground and surface water, soil and air [82]. In future, if undomesticated plants are commercialized for medicinal 
purposes, it is important that, for each species, the maximal residue levels (MRLs) for contaminants are determined [83].

The World Health Organization advocates for the use of medicinal plants and recommends further studies to identify the anti-hypertensive active phytochemical constituents of medicinal plants, quality standards and clinical efficacy [84]. Strong interdisciplinary collaboration that bridges the gap between modern biomedical medicine and traditional medicine is needed in order to develop effective medicine for the management of diabetes and cardiovascular diseases.

\section{Conclusions}

The epidemic of hypertension and the fact that there is an urgent need to improve the treatment of this disease is indisputable. Pharmaceutical drugs currently used in the treatment of hypertension often target the renin angiotensin system. Most inhibit the ACE1 pathway in some way; however, in recent years, a handful of drugs have been found to activate the ACE2 pathway, and in this way have a cardioprotective effect. Pharmaceutical drugs, however, pose certain challenges, such as the high cost and the resultant lack of availability to patients of a lower socioeconomic status, decreased efficacy with prolonged use, negative side effects and lack of safety of the use of certain drugs during pregnancy. Attention has therefore focused on the use of medicinal plants in the treatment of this disorder, with a number of plants showing anti-hypertensive properties through inhibition of the ACE1 pathway.

According to our knowledge, the effect of medicinal plants on the ACE2 pathway has not yet been elucidated. We believe that some of the phytochemicals found in traditional plants with anti-hypertensive properties may also be activating the ACE2 axis, leading to vasodilation and the subsequent decrease in total peripheral vascular resistance. However, it is clear from this review that scientifically sound information on the topic is scarce and further investigations into the active compounds and action of the plant materials with anti-hypertensive properties targeting the renin-angiotensin system are vital. We recommend further studies using appropriate animal models to assess the potential of ethno-medicinal plants in their use for the management of hypertension, particularly their potential in the ACE2-angiotensin-(1-7)-Mas receptor axis. The evaluation and authentication of traditional remedies, especially those used in the management of hypertension, will not only be invaluable for those who are dependent on traditional medicine to manage their hypertension, but this information could potentially prove to be useful for the future development of new pharmaceutical drugs. In fact, a significant proportion of pharmaceutical prescriptions currently in use are formulations derived from plants [85]. This may contribute to the formulation of an integrated healthcare system combining both ethno-medicinal and Western practices.

Author Contributions: T.T.N., B.T., P.D.L.-J. and A.S.-K. conceptualized the paper. T.T.N., B.T., P.D.L.-J. and A.S.-K. wrote and approved the final version of the manuscript. All authors have read and agreed to the published version of the manuscript.

Funding: This research received no external funding.

Conflicts of Interest: The authors declare no conflict of interest.

\section{References}

1. Olshansky, S.J.; Passaro, D.J.; Hershow, R.C.; Layden, J.; Carnes, B.A.; Brody, J.; Hayflick, L.; Butler, R.N.; Allison, D.B.; Ludwig, D.S. A potential decline in life expectancy in the United States in the 21st century. N. Engl. J. Med. 2005, 352, 1138-1145. [CrossRef] [PubMed]

2. James, P.A.; Oparil, S.; Carter, B.L.; Cushman, W.C.; Dennison-Himmelfarb, C.; Handler, J.; Lackland, D.T.; LeFevre, M.L.; MacKenzie, T.D.; Ogedegbe, O. 2014 evidence-based guideline for the management of high blood pressure in adults: Report from the panel members appointed to the Eighth Joint National Committee (JNC 8). JAMA 2014, 311, 507-520. [CrossRef] [PubMed]

3. Cappuccio, F.P.; Miller, M.A. Cardiovascular disease and hypertension in sub-Saharan Africa: Burden, risk and interventions. Intern. Emerg. Med. 2016, 11, 299-305. [CrossRef] [PubMed] 
4. Lloyd-Sherlock, P.; Beard, J.; Minicuci, N.; Ebrahim, S.; Chatterji, S. Hypertension among older adults in low-and middle-income countries: Prevalence, awareness and control. Int. J. Epidemiol. 2014, 43, 116-128. [CrossRef] [PubMed]

5. Hughes, G.D.; Aboyade, O.M.; Clark, B.L.; Puoane, T.R. The prevalence of traditional herbal medicine use among hypertensives living in South African communities. BMC Complement. Altern. Med. 2013, 13, 38.

6. Kearney, P.M.; Whelton, M.; Reynolds, K.; Muntner, P.; Whelton, P.K.; He, J. Global burden of hypertension: Analysis of worldwide data. Lancet 2005, 365, 217-223. [CrossRef]

7. Danaei, G.; Finucane, M.M.; Lu, Y.; Singh, G.M.; Cowan, M.J.; Paciorek, C.J.; Lin, J.K.; Farzadfar, F.; Khang, Y.-H.; Stevens, G.A. National, regional, and global trends in fasting plasma glucose and diabetes prevalence since 1980: Systematic analysis of health examination surveys and epidemiological studies with 370 country-years and 2. 7 million participants. Lancet 2011, 378, 31-40. [CrossRef]

8. Opie, L.H.; Seedat, Y.K. Hypertension in sub-Saharan African populations. Circulation 2005, 112, 3562-3568. [CrossRef]

9. Alsheikh-Ali, A.A.; Omar, M.I.; Raal, F.J.; Rashed, W.; Hamoui, O.; Kane, A.; Alami, M.; Abreu, P.; Mashhoud, W.M. Cardiovascular risk factor burden in Africa and the middle east: The Africa middle east cardiovascular epidemiological (ACE) study. PLoS ONE 2014, 9, e102830. [CrossRef]

10. Organization, W.H. Global Status Report on Noncommunicable Diseases 2014; World Health Organization: Geneva, Switzerland, 2014.

11. Seedat, Y.; Rayner, B. South African hypertension guideline 2011. Samj S. Afr. Med J. 2012, 102, 60-83. [CrossRef]

12. Duncan, A.C.; Jäger, A.K.; van Staden, J. Screening of Zulu medicinal plants for angiotensin converting enzyme (ACE) inhibitors. J. Ethnopharmacol. 1999, 68, 63-70. [CrossRef]

13. Steyn, K.; Bradshaw, D.; Norman, R.; Laubscher, R. Determinants and treatment of hypertension in South Africans: The first Demographic and Health Survey. S. Afr. Med. J. 2008, 98, 376-380. [PubMed]

14. Connor, M.; Rheeder, P.; Bryer, A.; Meredith, M.; Beukes, M.; Dubb, A.; Fritz, V. The South African stroke risk in general practice study. S. Afr. Med. J. 2005, 95.

15. Tipnis, S.R.; Hooper, N.M.; Hyde, R.; Karran, E.; Christie, G.; Turner, A.J. A human homolog of angiotensin-converting enzyme cloning and functional expression as a captopril-insensitive carboxypeptidase. J. Biol. Chem. 2000, 275, 33238-33243. [CrossRef]

16. Donoghue, M.; Hsieh, F.; Baronas, E.; Godbout, K.; Gosselin, M.; Stagliano, N.; Donovan, M.; Woolf, B.; Robison, K.; Jeyaseelan, R. A novel angiotensin-converting enzyme-related carboxypeptidase (ACE2) converts angiotensin I to angiotensin 1-9. Circ. Res. 2000, 87, e1-e9. [CrossRef]

17. Santos, R.A.; Ferreira, A.J.; Verano-Braga, T.; Bader, M. Angiotensin-converting enzyme 2, angiotensin-(1-7) and Mas: New players of the renin-angiotensin system. J. Endocrinol. 2013, 216, R1-R17. [CrossRef]

18. McKinney, C.A.; Fattah, C.; Loughrey, C.M.; Milligan, G.; Nicklin, S.A. Angiotensin-(1-7) and angiotensin-(1-9): Function in cardiac and vascular remodelling. Clin. Sci. 2014, 126, 815-827. [CrossRef]

19. Katovich, M.J.; Grobe, J.L.; Huentelman, M.; Raizada, M.K. Angiotensin-converting enzyme 2 as a novel target for gene therapy for hypertension. Exp. Physiol. 2005, 90, 299-305. [CrossRef]

20. Yamazato, M.; Yamazato, Y.; Sun, C.; Diez-Freire, C.; Raizada, M.K. Overexpression of angiotensin-converting enzyme 2 in the rostral ventrolateral medulla causes long-term decrease in blood pressure in the spontaneously hypertensive rats. Hypertension 2007, 49, 926-931. [CrossRef]

21. Varagic, J.; Ahmad, S.; Brosnihan, K.B.; Groban, L.; Chappell, M.C.; Tallant, E.A.; Gallagher, P.E.; Ferrario, C.M. Decreased cardiac Ang-(1-7) is associated with salt-induced cardiac remodeling and dysfunction. Ther. Adv. Cardiovasc. Dis. 2010, 4, 17-25. [CrossRef]

22. Santos, R.A.; Ferreira, A.J.; e Silva, A.C.S. Recent advances in the angiotensin-converting enzyme 2-angiotensin (1-7)-Mas axis. Exp. Physiol. 2008, 93, 519-527. [CrossRef] [PubMed]

23. Ferreira, A.J.; Santos, R.A.; Almeida, A.P. Angiotensin-(1-7): Cardioprotective effect in myocardial ischemia/reperfusion. Hypertension 2001, 38, 665-668. [CrossRef] [PubMed]

24. Zhong, J.-C.; Huang, D.-Y.; Yang, Y.-M.; Li, Y.-F.; Liu, G.-F.; Song, X.-H.; Du, K. Upregulation of angiotensin-converting enzyme 2 by all-trans retinoic acid in spontaneously hypertensive rats. Hypertension 2004, 44, 907-912. [CrossRef] [PubMed]

25. Popescu, S.M.; Scrieciu, M.; Mercuţ, V.; Ţuculina, M.; Dascălu, I. Hypertensive patients and their management in dentistry. ISRN Hypertens. 2013, 2013. [CrossRef] 
26. Doumas, M.; Tsakiris, A.; Douma, S.; Grigorakis, A.; Papadopoulos, A.; Hounta, A.; Tsiodras, S.; Dimitriou, D.; Giamarellou, H. Factors affecting the increased prevalence of erectile dysfunction in Greek hypertensive compared with normotensive subjects. J. Androl. 2006, 27, 469-477. [CrossRef]

27. Trinder, Y. Common and less common adverse effects of antihypertensives: A general practitioner's perspective: SA Hypertension Society Supplement. S. Afr. Fam. Pract. 2012, 54, 31-32. [CrossRef]

28. Liwa, A.C. Herbal and Alternative Medicine Utilization in Tanzanian Adults Admitted with Hypertension-Related Conditions; Weill Medical College of Cornell University: New York, NY, USA, 2015.

29. Opie, L.H. Calcium channel antagonists in the treatment of coronary artery disease: Fundamental pharmacological properties relevant to clinical use. Prog. Cardiovasc. Dis. 1996, 38, 273-290. [CrossRef]

30. Gurib-Fakim, A. Medicinal plants: Traditions of yesterday and drugs of tomorrow. Mol. Asp. Med. 2006, 27, 1-93. [CrossRef]

31. Reid, A.-M.; Oosthuizen, C.B.; Fibrich, B.D.; Twilley, D.; Lambrechts, I.A.; de Canha, M.N.; Rademan, S.; Lall, N. Traditional Medicine: The Ancient Roots of Modern Practice. In Medicinal Plants for Holistic Health and Well-Being; Elsevier: Amsterdam, The Netherlands, 2018; pp. 1-11.

32. Verma, R.; Hanif, K.; Sasmal, D.; Raghubir, R. Resurgence of herbal antihypertensives in management of hypertension. Curr. Hypertens. Rev. 2010, 6, 190-198. [CrossRef]

33. Eddouks, M.; Maghrani, M.; Lemhadri, A.; Ouahidi, M.-L.; Jouad, H. Ethnopharmacological survey of medicinal plants used for the treatment of diabetes mellitus, hypertension and cardiac diseases in the south-east region of Morocco (Tafilalet). J. Ethnopharmacol. 2002, 82, 97-103. [CrossRef]

34. Taylor, J.; Rabe, T.; McGaw, L.; Jäger, A.; Van Staden, J. Towards the scientific validation of traditional medicinal plants. Plant Growth Regul. 2001, 34, 23-37. [CrossRef]

35. De Wet, H.; Ramulondi, M.; Ngcobo, Z. The use of indigenous medicine for the treatment of hypertension by a rural community in northern Maputaland, South Africa. S. Afr. J. Bot. 2016, 103, 78-88. [CrossRef]

36. Mackraj, I.; Ramesar, S.; Singh, R.T. T. Violacea Lowers Blood Pressure and down Regulates AT1a Gene Expression in a Hypertensive Rat Model. FASEB J. 2007, 21, A1247.

37. Somova, L.; Shode, F.; Ramnanan, P.; Nadar, A. Antihypertensive, antiatherosclerotic and antioxidant activity of triterpenoids isolated from Olea europaea, subspecies africana leaves. J. Ethnopharmacol. 2003, 84, 299-305. [CrossRef]

38. Ramesar, S.; Baijnath, H.; Govender, T.; Mackraj, I. Angiotensin I-converting enzyme inhibitor activity of nutritive plants in KwaZulu-Natal. J. Med. Food 2008, 11, 331-336. [CrossRef]

39. Mackraj, I.; Ramesar, S. ACE Inhibitor Activity of Nutritive Plants in Kwa-Zulu Natal. FASEB J. 2007, 21 , A1247.

40. Raji, I.A.; Mugabo, P.; Obikeze, K. Effect of Tulbaghia violacea on the blood pressure and heart rate in male spontaneously hypertensive Wistar rats. J. Ethnopharmacol. 2012, 140, 98-106. [CrossRef]

41. Raji, I.; Obikeze, K.; Mugabo, P. Potential beneficial effects of Tulbaghia violacea William Henry Harvey (Alliaceae) on cardiovascular system-A review. Trop. J. Pharm. Res. 2015, 14, 1111-1117. [CrossRef]

42. Persson, I.A.L. The Pharmacological Mechanism of Angiotensin-converting Enzyme Inhibition by Green Tea, Rooibos and Enalaprilat-A Study on Enzyme Kinetics. Phytother. Res. 2012, 26, 517-521. [CrossRef]

43. Preuss, H.G.; Clouatre, D.; Mohamadi, A.; Jarrell, S.T. Wild garlic has a greater effect than regular garlic on blood pressure and blood chemistries of rats. Int. Urol. Nephrol. 2001, 32, 525-530. [CrossRef]

44. Sikora, J.; Markowicz-Piasecka, M.; Broncel, M.; Mikiciuk-Olasik, E. Extract of Aronia melanocarpa-modified hemostasis: In vitro studies. Eur. J. Nutr. 2014, 53, 1493-1502. [CrossRef] [PubMed]

45. Lacaille-Dubois, M.; Franck, U.; Wagner, H. Search for potential angiotensin converting enzyme (ACE)-inhibitors from plants. Phytomedicine 2001, 8, 47-52. [CrossRef] [PubMed]

46. Brixius, K.; Willms, S.; Napp, A.; Tossios, P.; Ladage, D.; Bloch, W.; Mehlhorn, U.; Schwinger, R.H. Crataegus special extract WS ${ }^{\circledR} 1442$ induces an endothelium-dependent, NO-mediated vasorelaxation via eNOS-phosphorylation at serine 1177. Cardiovasc. Drugs Ther. 2006, 20, 177-184. [CrossRef] [PubMed]

47. Rawat, P.; Singh, P.K.; Kumar, V. Anti-hypertensive medicinal plants and their mode of action. J. Herb. Med. 2016, 6, 107-118. [CrossRef]

48. Caballero-George, C.; Vanderheyden, P.M.; De Bruyne, T.; Shahat, A.-A.; Van den Heuvel, H.; Solis, P.N.; Gupta, M.P.; Claeys, M.; Pieters, L.; Vauquelin, G. In vitro inhibition of [3H]-angiotensin II binding on the human AT1 receptor by proanthocyanidins from Guazuma ulmifolia bark. Planta Med. 2002, 68, 1066-1071. [CrossRef] 
49. Ojeda, D.; Jiménez-Ferrer, E.; Zamilpa, A.; Herrera-Arellano, A.; Tortoriello, J.; Alvarez, L. Inhibition of angiotensin convertin enzyme (ACE) activity by the anthocyanins delphinidin-and cyanidin-3-O-sambubiosides from Hibiscus sabdariffa. J. Ethnopharmacol. 2010, 127, 7-10. [CrossRef]

50. Jabeen, Q.; Aslam, N. Hypotensive, angiotensin converting enzyme (ACE) inhibitory and diuretic activities of the aqueous-methanol extract of Ipomoea reniformis. Iran. J. Pharm. Res. IJPR 2013, 12, 769.

51. Jaarin, K.; Foong, W.D.; Yeoh, M.H.; Kamarul, Z.Y.N.; Qodriyah, H.M.S.; Azman, A.; Zuhair, J.S.F.; Juliana, A.H.; Kamisah, Y. Mechanisms of the antihypertensive effects of Nigella sativa oil in L-NAME-induced hypertensive rats. Clinics 2015, 70, 751-757. [CrossRef]

52. Shaw, H.-M.; Wu, J.-L.; Wang, M.-S. Antihypertensive effects of Ocimum gratissimum extract: Angiotensin-converting enzyme inhibitor in vitro and in vivo investigation. J. Funct. Foods 2017, 35, 68-73. [CrossRef]

53. Msomi, N.Z.; Simelane, M.B. Olea europaea subsp. africana (Oleaceae). In Active Ingredients from Aromatic and Medicinal Plants; InTech: London, UK, 2017.

54. Saputri, F.; Mun'im, A.; Lukmanto, D.; Aisyah, S.; Rinandy, J. Inhibition of angiotensin converting enzyme (ACE) activity by some Indonesia edible plants. Int. J. Pharm. Sci. Res. 2015, 6, 1054-1059.

55. Xie, Y.; Zhang, W. Antihypertensive activity of Rosa rugosa Thunb. flowers: Angiotensin I converting enzyme inhibitor. J. Ethnopharmacol. 2012, 144, 562-566. [CrossRef] [PubMed]

56. Huh, M.K. Inhibition of Angiotensin Converting Enzyme (ACE) by Viola Mandshurica Extraction. Eur. J. Adv. Res. Biol. Life Sci. Vol. 2015, 3.

57. Yodjun, M.; Karnchanatat, A.; Sangvanich, P. Angiotensin I-converting enzyme inhibitory proteins and peptides from the rhizomes of Zingiberaceae plants. Appl. Biochem. Biotechnol. 2012, 166, 2037-2050. [CrossRef] [PubMed]

58. Rentzsch, B.; Todiras, M.; Iliescu, R.; Popova, E.; Campos, L.A.; Oliveira, M.L.; Baltatu, O.C.; Santos, R.A.; Bader, M. Transgenic angiotensin-converting enzyme 2 overexpression in vessels of SHRSP rats reduces blood pressure and improves endothelial function. Hypertension 2008, 52, 967-973. [CrossRef] [PubMed]

59. Díez-Freire, C.; Vázquez, J.; de Adjounian, M.F.C.; Ferrari, M.F.; Yuan, L.; Silver, X.; Torres, R.; Raizada, M.K. ACE2 gene transfer attenuates hypertension-linked pathophysiological changes in the SHR. Physiol. Genom. 2006, 27, 12-19. [CrossRef]

60. Phillips, M.I.; Sumners, C. Angiotensin II in central nervous system physiology. Regul. Pept. 1998, 78, 1-11. [CrossRef]

61. Paizis, G.; Tikellis, C.; Cooper, M.E.; Schembri, J.M.; Lew, R.A.; Smith, A.I.; Shaw, T.; Warner, F.J.; Zuilli, A.; Burrell, L.M. Chronic liver injury in rats and humans upregulates the novel enzyme angiotensin converting enzyme 2. Gut 2005, 54, 1790-1796. [CrossRef]

62. Doobay, M.F.; Talman, L.S.; Obr, T.D.; Tian, X.; Davisson, R.L.; Lazartigues, E. Differential expression of neuronal ACE2 in transgenic mice with overexpression of the brain renin-angiotensin system. Am. J. Physiol. -Regul. Integr. Comp. Physiol. 2007. [CrossRef]

63. Liu, C.X.; Hu, Q.; Wang, Y.; Zhang, W.; Ma, Z.Y.; Feng, J.B.; Wang, R.; Wang, X.P.; Dong, B.; Gao, F. Angiotensin-converting enzyme (ACE) 2 overexpression ameliorates glomerular injury in a rat model of diabetic nephropathy: A comparison with ACE inhibition. Mol. Med. 2011, 17, 59-69. [CrossRef]

64. Diz, D.I.; Garcia-Espinosa, M.A.; Gegick, S.; Tommasi, E.N.; Ferrario, C.M.; Tallant, E.A.; Chappell, M.C.; Gallagher, P.E. Injections of angiotensin-converting enzyme 2 inhibitor MLN4760 into nucleus tractus solitarii reduce baroreceptor reflex sensitivity for heart rate control in rats. Exp. Physiol. 2008, 93, 694-700. [CrossRef]

65. Chamsi-Pasha, M.A.; Shao, Z.; Tang, W.W. Angiotensin-converting enzyme 2 as a therapeutic target for heart failure. Curr. Heart Fail. Rep. 2014, 11, 58-63. [CrossRef]

66. Huentelman, M.J.; Grobe, J.L.; Vazquez, J.; Stewart, J.M.; Mecca, A.P.; Katovich, M.J.; Ferrario, C.M.; Raizada, M.K. Protection from angiotensin II-induced cardiac hypertrophy and fibrosis by systemic lentiviral delivery of ACE2 in rats. Exp. Physiol. 2005, 90, 783-790. [CrossRef] [PubMed]

67. Chappell, M.C.; Modrall, J.; Diz, D.I.; Ferrario, C. Novel aspects of the renal renin-angiotensin system: Angiotensin-(1-7), ACE2 and blood pressure regulation. Contrib. Nephrol. 2004, 143, 77-89. [PubMed]

68. Bai, S.; Huang, Z.-G.; Chen, L.; Wang, J.-T.; Ding, B.-P. Effects of felodipine combined with puerarin on ACE2-Ang (1-7)-Mas axis in renovascular hypertensive rat. Regul. Pept. 2013, 184, 54-61. [CrossRef] [PubMed] 
69. Qiao, W.; Wang, C.; Chen, B.; Zhang, F.; Liu, Y.; Lu, Q.; Guo, H.; Yan, C.; Sun, H.; Hu, G. Ibuprofen attenuates cardiac fibrosis in streptozotocin-induced diabetic rats. Cardiology 2015, 131, 97-106. [CrossRef]

70. Arumugam, S.; Thandavarayan, R.A.; Palaniyandi, S.S.; Giridharan, V.V.; Arozal, W.; Sari, F.R.; Soetikno, V.; Harima, M.; Suzuki, K.; Kodama, M. Candesartan cilexetil protects from cardiac myosin induced cardiotoxicity via reduction of endoplasmic reticulum stress and apoptosis in rats: Involvement of ACE2-Ang (1-7)-mas axis. Toxicology 2012, 291, 139-145. [CrossRef]

71. Cao, L.; Xun, J.; Jiang, X.; Tan, R. Propofol up-regulates Mas receptor expression in dorsal root ganglion neurons. Die Pharm. Int. J. Pharm. Sci. 2013, 68, 677-680.

72. Sukumaran, V.; Veeraveedu, P.T.; Gurusamy, N.; Lakshmanan, A.P.; Yamaguchi, K.I.; Ma, M.; Suzuki, K.; Kodama, M.; Watanabe, K. Telmisartan acts through the modulation of ACE-2/ANG 1-7/mas receptor in rats with dilated cardiomyopathy induced by experimental autoimmune myocarditis. Life Sci. 2012, 90, 289-300. [CrossRef]

73. Hernández Prada, J.A.; Ferreira, A.J.; Katovich, M.J.; Shenoy, V.; Qi, Y.; Santos, R.A.; Castellano, R.K.; Lampkins, A.J.; Gubala, V.; Ostrov, D.A. Structure-based identification of small-molecule angiotensin-converting enzyme 2 activators as novel antihypertensive agents. Hypertension 2008, 51, 1312-1317. [CrossRef]

74. Flores-Monroy, J.; Ferrario, C.M.; Valencia-Hernández, I.; Hernández-Campos, M.E.; Martínez-Aguilar, L. Comparative effects of a novel angiotensin-converting enzyme inhibitor versus captopril on plasma angiotensins after myocardial infarction. Pharmacology 2014, 94, 21-28. [CrossRef]

75. Wang, Y.; Li, C.; Ouyang, Y.; Yu, J.; Guo, S.; Liu, Z.; Li, D.; Han, J.; Wang, W. Cardioprotective effects of Qishenyiqi mediated by angiotensin II type 1 receptor blockade and enhancing angiotensin-converting enzyme 2. Evid. Based Complement. Altern. Med. 2012, 2012. [CrossRef] [PubMed]

76. Liu, Q.; Tian, J.; Xu, Y.; Li, C.; Meng, X.; Fu, F. Protective effect of RA on myocardial infarction-induced cardiac fibrosis via AT1R/p38 MAPK pathway signaling and modulation of the ACE2/ACE ratio. J. Agric. Food Chem. 2016, 64, 6716-6722. [CrossRef] [PubMed]

77. Zhang, S.; Xiangqun, L.; Huanqin, C.; Xin, Y.; Qiongqiong, G.; Min, W.; Xingpo, L. Effects of Baicalin on the NF- $\mathrm{kB}$ and ACE2 Protein Expression in Atherosclerosis of ApoE-/-Mice Induced by Hyperlipaemia. Med. Plant 2013, 4.

78. Tabassum, N.; Ahmad, F. Role of natural herbs in the treatment of hypertension. Pharmacogn. Rev. 2011, 5, 30. [CrossRef] [PubMed]

79. Wilburn, A.J.; King, D.S.; Glisson, J.; Rockhold, R.W.; Wofford, M.R. The natural treatment of hypertension. J. Clin. Hypertens. 2004, 6, 242-248. [CrossRef]

80. Sofowora, A. Medicinal Plants and Traditional Medicine in Africa; Karthala: Paris, France, 1982.

81. Balick, M.J.; Cox, P.A. Plants, People, and Culture: The Science of Ethnobotany; Scientific American Library: New York, NY, USA, 1996.

82. Kumar, S.; Kaushik, G.; Dar, M.A.; Nimesh, S.; Lopez-Chuken, U.J.; Villarreal-Chiu, J.F. Microbial degradation of organophosphate pesticides: A review. Pedosphere 2018, 28, 190-208. [CrossRef]

83. Quinn, L.; de Vos, J.; Fernandes-Whaley, M.; Roos, C.; Bouwman, H.; Kylin, H.; Pieters, R.; van den Berg, J. Pesticide use in South Africa: One of the largest importers of pesticides in Africa. In Pesticides in the Modern World_Pesticides Use and Management; IntechOpen: London, UK, 2011.

84. WHO. WHO Monographs on Selected Medicinal Plants; World Health Organization: Geneva, Switzerland, 1999; Volume 2.

85. Rates, S.M.K. Plants as source of drugs. Toxicon 2001, 39, 603-613. [CrossRef]

(C) 2020 by the authors. Licensee MDPI, Basel, Switzerland. This article is an open access article distributed under the terms and conditions of the Creative Commons Attribution (CC BY) license (http://creativecommons.org/licenses/by/4.0/). 